Evaluation of a Bovine Rapid Visual PAG ELISA Test and Transabdominal Ultrasonography for Early Pregnancy Diagnosis in Awassi Sheep

\author{
Mehmet AKKÖSE \\ Ceylanpinar Agricultural Enterprise, General Directorate of Agricultural Enterprises, Sanliurfa, Turkey \\ https://orcid.org/0000-0001-7517-4927 \\ $\bowtie$ : akkosem2012@gmail.com
}

\section{ABSTRACT}

The aim of this study was to evaluate two different methods (a bovine rapid visual PAG ELISA test and transabdominal ultrasonography) for early diagnosis of pregnancy in Awassi sheep. The ewes used in this study $(n=50)$ were hand-mated in June of 2019 and lambed in October of 2019. Pregnancy diagnosis was performed 34-38 days after mating by rapid visual PAG ELISA test and transabdominal ultrasonography in standing position. The diagnostic test characteristics of both methods were calculated using lambing results as a gold standard. According to the lambing results, it was determined that, of the 50 ewes, $42(84 \%)$ were pregnant and $8(16 \%)$ were not. The sensitivity, specificity, positive predictive value, negative predictive value and accuracy of rapid visual PAG ELISA and transabdominal ultrasonography were $97.6 \%, 62.5 \%, 93.2 \%$, $83.3 \%, 92 \%$ and $95.2 \%, 100 \%, 100 \%, 80 \%, 96 \%$, respectively. In McNemar's analysis, no difference was found between the pregnancy diagnosis methods and lambing results. In conclusion, both rapid visual PAG ELISA and transabdominal ultrasonography in standing position proved to be reliable and practical methods for pregnancy diagnosis as of day 34 post-mating in Awassi ewes.
\end{abstract}

\section{Research Article}

$\begin{array}{ll}\text { Article History } & \\ \text { Received } & : 31.12 .2019 \\ \text { Accepted } & : 02.04 .2020\end{array}$

\author{
Keywords \\ Pregnancy diagnosis \\ Pregnancy-associated \\ glycoproteins \\ Transabdominal ultrasound \\ Awassi sheep
}

\title{
İvesi Koyunlarında Gebeliğin Erken Teşhisi İçin Sığır Hızlı Görsel PAG ELISA Testi ve Transabdominal
} Ultrasonografinin Değerlendirilmesi

\section{ÖZET}

Bu çalışmanın amacı, İvesi koyunlarında erken gebelik teşhisi için iki farklı yöntemi (bir sığır hızlı görsel PAG ELISA testi ve transabdominal ultrasonografi) değerlendirmektir. Çalışmada kullanılan koyunlar ( $\mathrm{n}=50$ ), Haziran 2019'da elde aşım yöntemi ile koça verildi ve Kasım 2019'da kuzuladı. Gebelik teşhisi, aşımdan 3438 gün sonra hızlı görsel PAG ELISA ve ayakta transabdominal ultrasonografi ile yapıldı. Kuzulama sonuçları referans alınarak her iki gebelik testinin tanısal test özellikleri hesaplandı. Kuzulama sonucuna göre 50 koyunun 42'sinin (\% 84) gebe olduğu, 8'inin (\%16) ise gebe olmadiğı belirlendi. Hızlı görsel PAG ELISA'nın duyarlılığı, özgüllüğü, pozitif prediktif değeri, negatif prediktif değeri ve doğruluğu sirasiyla \% 97.6, \% 62.5, \% 93.2, \% 83.3 ve \% 92 iken; transabdominal ultrasonografinin \% 95.2, \% 100, \% 100, \% 80, \% 96'ydı. McNemar' analizinde her iki gebelik teşhis yöntemi ile kuzulama sonuçları arasında farklılık belirlenmedi. Sonuç olarak İvesi koyunlarında gebelik teşhisi için hızlı görsel PAG ELISA ve ayakta transabdominal ultrasonografi yöntemlerinin her ikisi de aşımdan sonraki 34 'üncü günden itibaren güvenilir ve pratik yöntemlerdir.

\section{Araştırma Makalesi}

\section{Makale Tarihçesi}

Geliş Tarihi : 31.12 .2019

Kabul Tarihi : 02.04.2020

\section{Anahtar Kelimeler \\ Gebelik teşhisi \\ Gebelikle ilişkili glikoproteinler \\ Transabdominal ultrason \\ İvesi koyunu}

To Cite Cite : Akkose M 2020. Evaluation of a Bovine Rapid Visual PAG ELISA Test and Transabdominal Ultrasonography for Early Pregnancy Diagnosis in Awassi Sheep. KSU J. Agric Nat 23 (5): 1366-1372. DOI: 10.18016/ ksutarimdoga.vi.668707. 


\section{INTRODUCTION}

The sheep industry stands out as a promising economic sector. Sheep breeding has an important place in Turkey's economy in terms of meat, milk, wool and leather production. The milk yield of Awassi sheep, which is one of the highest milk-producing sheep breeds native to Turkey, can reach up to $250-300 \mathrm{~kg}$ in breeder flocks (Taşan, 2016). The fattening performance of male lambs can vary from $35 \mathrm{~kg}$ to 42 $\mathrm{kg}$ depending on the rearing period and system (Kul and Akcan, 2002; Tekel et al., 2007; Şireli and Tekel, 2013). Recent studies have shown that while consumer demand for different types of meat is changing, sheep meat consumption is increasing worldwide (Kandemir et al., 2019). Especially the increased demand for lamb meat requires increased reproductive performance. The early diagnosis of pregnancy in sheep enables strategic interventions in herd management, including the nutrition, culling or separation of sheep. Nonpregnant ewes can be either re-bred in the breeding season, fed only for wool and leather production or culled to reduce feeding costs. Non-pregnant lambs can be marketed at a higher price before transitioning into adulthood. Furthermore, the involuntary culling of pregnant ewes can be prevented. The separation of the flock into pregnant and non-pregnant groups might reduce productive and reproductive losses caused by abortions, stillbirths and birth of weak lambs (Karen et al., 2001; Ulusoy and Kaymaz, 2009; Chaves et al., 2017).

Several methods can be used for pregnancy diagnosis in sheep, and transabdominal ultrasonography is one of the most common. Transabdominal ultrasonography can be used with a sensitivity of $100 \%$ as from the 39 th day of pregnancy (Jones et al., 2016), and with an accuracy of $100 \%$ as from the 40 th day of pregnancy (Aziz and Lazim, 2012). Despite its high efficiency in the diagnosis of pregnancy in sheep, ultrasonography also has some practical limitations related to the facilities required for examination, positioning of ewes for examination, availability and portability of equipment, type and frequency of transducer, and cost of equipment (Roberts et al., 2019).

Pregnancy-associated glycoproteins (PAGs) are produced in the fetomaternal interface of the ruminant placenta and released into the intercotyledonary space during pregnancy (Sousa et al., 2006). The presence of PAGs in the maternal circulation allows for an early diagnosis of pregnancy in cows (Akköse et al., 2019; Akköse and Çebi Şen, 2019), sheep (Uçar et al., 2018; Alkan et al., 2020) and goats (Gonzalez et al., 1999; Tandiya et al., 2013). Enzyme-linked immunosorbent assay (ELISA) tests, which can be used in the field, have been developed to detect PAGs in the maternal circulation (serum, plasma or whole blood samples) and milk of cattle (BioPRYN, Idexx Bovine Pregnancy Test, Idexx Visual Pregnancy Test, Idexx Milk
Pregnancy Test, Idexx Rapid Visual Pregnancy Test). While Xie et al. (1991) detected immunological and structural similarities between ovine and bovine PAG molecules, it has also been reported that bovine and ovine PAGs can exhibit spatially and temporally distinct expression patterns during pregnancy at species or breed level (Green et al., 2000; Lobago et al., 2009; Mercadante et al., 2013). PAG ELISA pregnancy tests commercially validated for cattle have been used in various Brasilian and European sheep breeds (Rovani et al., 2016; Chaves et al., 2017; Steckeler et al., 2018). It is stated that PAG profiles in the peripheral blood can vary between sheep breeds; therefore, determining the specific PAG profile of breeds native to Turkey is important for improved reproductive management (Kaplan et al., 2019). The aim of this study was to evaluate the diagnostic reliability of a bovine rapid visual PAG ELISA test and transabdominal ultrasonography in standing position for early pregnancy diagnosis in Awassi sheep using lambing results as a gold standard.

\section{MATERIAL and METHOD}

\section{Material}

\section{Animal Management}

This study was approved by the Local Ethics Committee for Animal Experiments of Harran University (Protocol no: 2019/006/01-05).

The trial was conducted from June to December 2019, in the Sanliurfa province located in the Southeaster Anatolia Region of Turkey, using Awassi sheep. Fifty Awassi ewes, aged 2-5 years and weighing 40-60 kg, were used in this study. All animals were maintained under the same environmental and nutritional conditions. All ewes had access to pasture (wheat stubble) during the summer and were fed additional concentrate.

Estrus detection was performed twice a day using teaser rams, and ewes in heat were hand-mated. Ewes, to be mated by certain rams, were listed beforehand. The mating and lambing records of all ewes were maintained in the herd management system of the enterprise.

\section{Method}

\section{Blood Collection and Rapid Visual PAG ELISA}

Blood samples were collected by jugular venipuncture into $10^{-} \mathrm{ml}$ dry vacutainer tubes (Hematube). Transabdominal ultrasonography was performed after blood collection. Sera were separated 1-2 hours after blood collection at room temperature.

Rapid visual PAG ELISA (Idexx rapid visual pregnancy test) was performed in the field, according to the manufacturer's instructions. Briefly, $100 \mu \mathrm{l}$ serum and positive and negative controls of assay were added into anti-PAG coated wells. Next, the detector 
solution was added to each well and incubated for 7 minutes at room temperature. Following incubation, the wells were washed 3 times with distilled water. Subsequently, the conjugate solution was added to all wells and incubated for 7 minutes at room temperature. After incubation, the wells were washed 3 times with distilled water. Later, the substrate solution was added to all wells and allowed to incubate for 7 minutes at room temperature. At the end of the incubation period, a stop solution was added to all wells, and the test wells were compared to the positive and negative controls for colour change. Rapid visual PAG ELISA results are interpreted based on the colour reaction in the wells. A positive well is blue, while a negative well is transparent. If the colour of the test well is bluer than that of the negative control, the result is positive (pregnant). However, if the colour of the test well is the same with that of the negative control or more transparent, the result is negative (non-pregnant).

\section{Transabdominal Ultrasonography}

For pregnancy diagnosis, right inguinal transabdominal ultrasonography was performed in all ewes in standing position between days $34-38$ postmating using an ultrasound device (Hasvet 838). Pregnancy was diagnosed based on the observation of a fluid-filled uterus and placentomes or a fetus. All ultrasonographic examinations were performed by the same veterinarian.

\section{Statistical Analysis}

Lambing results were used as a gold standard to test the accuracy of both methods in pregnancy diagnosis. For the prediction of the diagnostic characteristics of rapid visual PAG ELISA and transabdominal ultrasonography, data were classified as follows: correct negative (a), false positive (b), false negative (c) and correct positive (d) results. Subsequently, sensitivity $[d /(d+c) X 100]$, specificity $[a /(a+b) X 100]$, positive predictive value (PPV) $[d /(d+b) X 100]$, negative predictive value $(\mathrm{NPV})[\mathrm{a} /(\mathrm{a}+\mathrm{c}) \mathrm{X} 100]$, and accuracy $[(a+d) /(a+b+d+c) X 100]$ were calculated for each pregnancy diagnosis method. Kappa analysis was performed to determine the agreement of rapid visual PAG ELISA and transabdominal ultrasonography with the lambing results. McNemar's test and the comparison of the receiver operating characteristic (ROC) curves were used to determine whether there was any significant difference between the results of the two pregnancy diagnosis methods and lambing results (Yağanoğlu and Topal, 2018; Roberts et al., 2019). The Kappa coefficients were classified as indicating a poor $(\leq 0.20)$, fair $(0.21-0.40)$, moderate (0.41-0.60), good (0.61-0.80) and very good (0.81-1.00) agreement (Altman, 1991). Statistical calculations were performed using Statistical Package for Social Sciences (SPSS) version 24.0 at significance level of $\mathrm{p}<0.05$.

\section{RESULTS and DISCUSSION}

Out of the 50 ewes used in the present study, 42 lambed and 8 did not lamb. To evaluate the pregnancy outcomes of each pregnancy diagnosis method in ewes, a $2 \mathrm{X} 2$ contingency table was constructed (Table 1) and test characteristics were calculated for transabdominal ultrasonography and rapid visual PAG ELISA (Table 2). While 2 ewes were diagnosed false negative with transabdominal ultrasonography, 3 ewes were diagnosed false positive and 1 ewe was diagnosed false negative with rapid visual PAG ELISA for pregnancy.

Table 1. A 2x2 contingency table for rapid visual PAG ELISA and transabdominal ultrasonography Cizelge 1. Hızlı görsel PAG ELISA ve transabdominal ultrasonografi için $2 X 2$ olasılık tablosu

\begin{tabular}{|c|c|c|c|c|c|c|c|}
\hline & & \multicolumn{3}{|c|}{$\begin{array}{l}\text { Rapid Visual PAG ELISA } \\
\text { (Hızlı Görsel PAG ELISA) }\end{array}$} & \multicolumn{3}{|c|}{$\begin{array}{l}\text { Transabdominal Ultrasonography } \\
\text { (Transabdominal Ultrasonografi) }\end{array}$} \\
\hline & & $\begin{array}{l}\text { Non-pregnant } \\
\text { (Gebe değil) }\end{array}$ & $\begin{array}{c}\text { Pregnant } \\
\text { (Gebe) }\end{array}$ & $\begin{array}{c}\text { Total } \\
\text { (Toplam) }\end{array}$ & $\begin{array}{l}\text { Non-pregnant } \\
\text { (Gebe değgil) }\end{array}$ & $\begin{array}{l}\text { Pregnant } \\
\text { (Gebe) }\end{array}$ & $\begin{array}{c}\text { Total } \\
\text { (Toplam) }\end{array}$ \\
\hline \multirow{3}{*}{$\begin{array}{l}\text { Lambing } \\
\text { records } \\
\text { (Kuzulama } \\
\text { sonuçları) }\end{array}$} & $\begin{array}{l}\text { Did Not Lambed } \\
\text { (Kuzulamadı) } \\
\text { Lambed }\end{array}$ & $5(\mathrm{cn})$ & $3(\mathrm{fp})$ & 8 & $8(\mathrm{cn})$ & $0(\mathrm{fp})$ & 8 \\
\hline & (Kuzuladl) & $1(\mathrm{fn})$ & $41(\mathrm{cp})$ & 42 & $2(\mathrm{fn})$ & $40(\mathrm{cp})$ & 42 \\
\hline & Total (Toplam) & 6 & 44 & 50 & 10 & 40 & 50 \\
\hline
\end{tabular}

cn: correct negative (doğru negatif); cp: correct positive (doğru pozitif); fn: false negative (yanlış negatif); fp: false positive (yanlış pozitif)

In this study, pregnancy diagnosis was performed $34-38$ days after mating. Upon determining that the uterus hung from the intrapelvic area to the abdominal cavity on the 32nd day of pregnancy in Akkaraman sheep, Küplülü et al. (2002) suggested the use of the transabdominal technique for the diagnosis of pregnancy by ultrasound examination, as of day 32. The application of transabdominal ultrasonography in the sitting position has been reported to produce better results than the standing position for early pregnancy diagnosis (Gürler and Kaymaz, 2011). However, maintaining animals in a sitting position is time-consuming and laborsome. In the present study, sheep were restrained in the 
standing position by an employee, and the hairless area of the right inguinal region was scanned with a transducer for the diagnosis of pregnancy by ultrasound examination.

The sensitivity and specificity of transabdominal ultrasonography in standing position were determined to be $95.2 \%$ and $100 \%$, respectively. Similarly, Jones et al. (2016) reported that, in sheep the sensitivity and specificity of this method were $83 \%$ and $100 \%$, respectively, on day 30 postinsemination, and were both $100 \%$ on day 39 postinsemination. The positive and negative predictive values of transabdominal ultrasonography in standing position in the present study were $100 \%$ and $80 \%$, respectively. The uterus could still be located in the pelvic cavity before the 40th day of pregnancy (Crilly et al., 2017). In the present study, the false negative results (two ewes were diagnosed false negative) were attributed to the uterus having not descended into the abdominal cavity at the time of pregnancy diagnosis. Aziz and Lazim (2012) reported that the accuracy of transabdominal ultrasonography increases from $80 \%$ between days 28-32 of pregnancy to $100 \%$ between days $40-43$ days in Awassi sheep. In agreement with this report, the accuracy of transabdominal ultrasonography was determined to be $96 \%$ in the present study.

Table 2. Diagnostic test characteristics of rapid visual PAG ELISA and transabdominal ultrasonography Cizelge 2. Hizl görsel PAG ELISA ve transabdominal ultrasonografinin tanisal test özellikleri

\begin{tabular}{lcc}
\hline & $\begin{array}{c}\text { Rapid Visual PAG ELISA } \\
\text { (Hızlı Görsel PAG ELISA) }\end{array}$ & $\begin{array}{c}\text { Transabdominal Ultrasonography } \\
\text { (Transabdominal Ultrasonografi) }\end{array}$ \\
\hline Sensitivity (\%) (Duyarlılık (\%)) & 97.6 & 95.2 \\
Specificity (\%) (Özgüllük (\%)) & 62.5 & 100 \\
Positive predictive value (\%) & & 100 \\
(Pozitif prediktif değer (\%)) & 93.2 & 80 \\
Negative predictive value (\%) & & 96 \\
(Negatif prediktif değer (\%)) & 83.3 & 96 \\
Accuracy (\%) Doğruluk (\%) & 92 & \\
\hline
\end{tabular}

The sensitivity determined for rapid visual PAG ELISA (97.6\%) in the present study was in agreement with sensitivities previously reported in Santa Ines ewes 26-30 days after mating (Chaves et al., 2020), in Dorper, Shropshire, Hampshire and crosbred (Dorset x Polypay) sheep 30-90 days after mating (Roberts et al., 2019) and in German Blackhead and Merino sheep in mid-pregnancy (range: 71-120 days) (Steckeler et al., 2018). Furthermore, sensitivities similar to the sensitivity determined for the rapid visual PAG ELISA in the present study were reported for the "Idexx visual pregnancy test" in Santa Ines ewes 30 days after laparoscopic insemination (Chaves et al., 2017) and for the "Idexx bovine pregnancy test" in Corriedela and Ile de France x Texel sheep throughout pregnancy (Rovani et al., 2016). On the other hand, Kaplan et al. (2019) reported a low sensitivity for the "Idexx bovine pregnancy test" before the 56th day of pregnancy in Konya Merino sheep. In addition, Chaves et al. (2017) determined a lower sensitivity for the "Idexx visual pregnancy test" on day 26 post-mating compared to day 28 post-mating ( 73.17 versus 92.68 , respectively).

In the present study, the specificity of rapid visual PAG ELISA was low (62.5\%). This was attributed to early embryonic deaths having occurred before the day of pregnancy diagnosis. As PAGs are pregnancyspecific molecules, sheep have a long anestrus period, and controlled mating is practiced at farm level, PAGs detected in the maternal circulation are associated with pregnancy and cannot be of residual nature.
Furthermore, in ruminants, PAGs can persist in maternal circulation several days after embryonic death, which may result in false positive results (Hussein et al., 2017). Based on this information, it can be said that pregnancy occurred but was not maintained in ewes diagnosed false positive (3 of the 8 non-pregnant ewes).

Rapid visual PAG ELISA and transabdominal ultrasonography were found to be in strong agreement with the lambing results (Table 3). Roberts et al. (2019) reported a strong agreement for "Idexx rapid visual pregnancy test" and transabdominal ultrasonography with lambing results (0.900 and 0.974 , respectively) 30-90 days after breeding in sheep. Similar Kappa coefficients were computed for the two early pregnancy diagnosis methods in the present study.

In the Kappa analysis, values between 0.61 and 0.80 indicated a good agreement and values between 0.81 and 1.0 indicated a very good agreement (Altman, 1991). In the present study, while there was a very good agreement between transabdominal ultrasonography and the lambing results, the agreement between rapid visual PAG ELISA and the lambing results was slightly lower. This lower agreement was attributed to pregnancy losses having occurred before pregnancy diagnosis. In research in cattle, it was determined that PAGs had a long halflife and could be detected in the maternal circulation for a few days after the death of the embryo (Pohler et al., 2016). Therefore, embryonic deaths cause false 
positive results. In research in sheep, lower serum PAG levels were measured in Romanov crossbred ewes with pregnancy loss (Hussein et al., 2017). However, further research is needed on the serum PAG profile of ewes in the event of embryonic death.

Table 3. Kappa analysis results of rapid visual PAG ELISA and transabdominal ultrasonography versus lambing for pregnancy diagnosis in Awassi sheep 34-38 days after mating

Cizelge 3. Ivesi koyunlarında aşımdan 34 - 38 gün sonra gebelik teşhisi için hızlı görsel PAG ELISA ve transabdominal ultrasonografinin kuzulamaya karş̧ı Kappa analizi sonuçları

Rapid Visual PAG ELISA Transabdominal Ultrasonography (Hızlı Görsel PAG ELISA) (Transabdominal Ultrasonografi)

\begin{tabular}{lcc}
\hline Degree of Agreement (Uyumun Derecesi) & 0.669 & 0.865 \\
p-value (p-değeri) & $<0.001$ & $<0.001$ \\
\hline
\end{tabular}

In McNemar's analysis, there was no significant difference between either rapid visual PAG ELISA or transabdominal ultrasonography and the lambing results. According to the comparison of the ROC curves (Table 4, Figure 1), the area under the curve (AUC) was larger for transabdominal ultrasonography compared to rapid visual PAG ELISA. However, the difference between the two pregnancy diagnosis methods for AUC (0.176) was statistically insignificant.

The two pregnancy diagnosis methods having determined to show a strong agreement and insignificant differences indicates that both methods are reliable for early pregnancy diagnosis in sheep. The choice of method depends on several factors, including among others the cost of diagnosis, the access of shepherds to veterinary services, and herd management. Rapid visual PAG ELISA costs nearly $4 \$$ per analysis. The cost of pregnancy diagnosis by ultrasonography varies between $8 \$$ and $15 \$$ per sheep, according to the base prices determined by the Chamber of Veterinary Surgeons. Although its cost is higher, when performed by a veterinarian, ultrasonography enables the detection of possible reproductive pathologies. Thereby, such cases can be managed at an early stage, and no additional fee is paid for this diagnosis. However, the transport costs of highland shepherds remote from veterinary services add up to the cost of pregnancy diagnosis. In view of such situations, further research is needed to analyse the cost-effectiveness of pregnancy diagnosis methods in small ruminants.

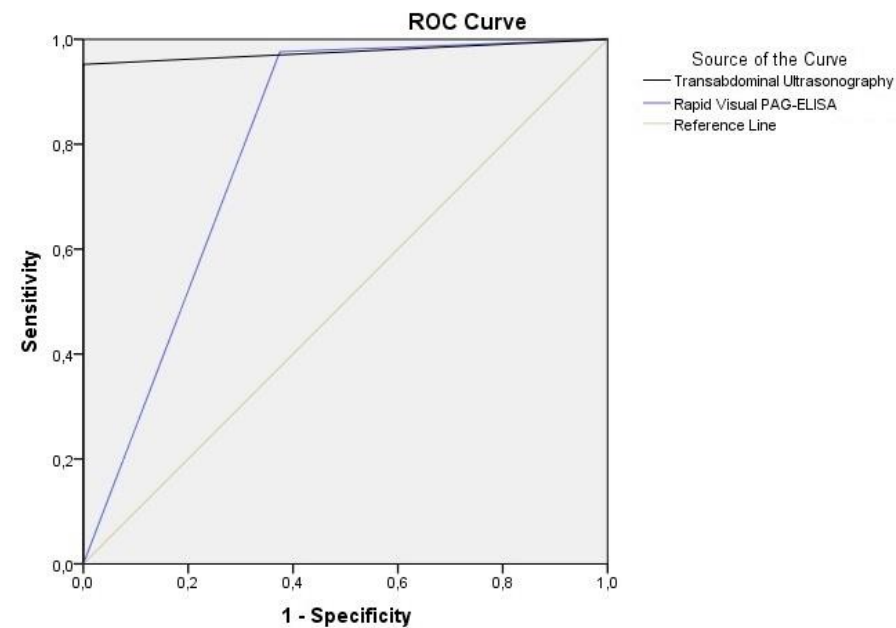

Figure 1. Receiver operating characteristic (ROC) curves of each pregnancy diagnosis method

Şekil 1. Her bir gebelik teşhis yönteminin ROC ĕgrileri

Table 4. The results of the receiver operating characteristic (ROC) analysis of rapid visual PAG ELISA and transabdominal ultrasonography in Awassi sheep 34-38 d after mating

Cizelge 4. Ivesi koyunlarında aşımdan 34-38 gün sonra hılı görsel PAG ELISA ve transabdominal ultrasonografinin $R O C$ analizi sonuçları

\begin{tabular}{lccc}
\multicolumn{1}{c}{ Sonografinin ROC analizi Sonuçları } & $A U C$ & $S E$ & $95 \% C I$ \\
\hline $\begin{array}{l}\text { Rapid visual PAG ELISA } \\
\text { (Hizlı Görsel PAG ELISA) }\end{array}$ & 0.801 & 0.0923 & 0.663 to 0.900 \\
$\begin{array}{l}\text { Transabdominal Ultrasonography } \\
\text { (Transabdominal Ultrasonografi) }\end{array}$ & 0.976 & 0.0166 & 0.887 to 0.999 \\
\hline
\end{tabular}

AUC: Area under curve (eğri altında kalan alan); SE: Standard error (Standart hata); 95\% CI: 95\% Confidence interval (\% 95 güven sinırları)

\section{CONCLUSION}

In conclusion, both rapid visual PAG ELISA commercially validated for cattle and transabdominal ultrasonography in standing position are practical and reliable for pregnancy diagnosis as of day 34 post- mating in Awassi ewes. Rapid visual PAG ELISA can be easily applied in field conditions. Further studies are needed to exhaustive investigate the effects of embryonic deaths on serum PAG profile in sheep. 


\section{ACKNOWLEDGEMENTS}

This research did not receive any specific grant from funding agencies in the public, commercial, or not-forprofit sectors.

\section{REFERENCES}

Akköse M, Cebi-Sen C, Kirmit A, Korkmaz O, Yazlik MO, Gocen M, Kuru M, Akçay E 2019. Pregnancyassociated glycoproteins (PAGs) and progesterone concentrations in Holstein heifers following two methods of estrus synchronization. Veterinaria México OA, 6(2): 1-11. https://doi.10.22201/ fmvz.24486760e.2019.2.646

Akköse M, Cebi-Sen C 2019. Sütçü sığırlarda erken gebelik tanısı. Hayvansal Üretim, 60(2): 171-179. https://doi.org/10.29185/hayuretim. 458620

Alkan H, Kivrak MB, Satilmis F, Tekindal MA, Dinc DA 2020. Detection of twin pregnancies in ewes by pregnancy-associated glycoprotein assay and transabdominal ultrasonography. 72, 106399. https://doi.org/10.1016/j.domaniend.2019.106399.

Altman DG 1991. Practical statistics for medical research. Chapman and Hall, London, p., 404.

Aziz DM, Lazim EH 2012. Transabdominal ultrasonography in standing position for pregnancy diagnosis in Awassi ewes. Small Ruminant Research, 107(2-3): 131-135. http://dx.doi.org /10.1016/ j.smallrumres.2012.05.007

Chaves CMS, Costa RLD, Duarte KMR, Machado DC, Paz CCP, Beltrame RT 2017. Visual ELISA for detection of pregnancy-associated glycoproteins (PAGs) in ewe serum. Theriogenology, 97: 78-82. https:/doi.org/10.1016/j.theriogenology.2017.04.026

Chaves CMS, da Costa RLD, Duarte KMR, Beltrame RT, Quirino CR 2020. Evaluation of a cattle rapid test for early pregnancy diagnosis in sheep. Tropical Animal Health and Production, 52(3): 1345-1349. https://doi.org/10.1007/s11250-019-02130-7

Crilly JP, Politis AP, Hamer K 2017. Use of ultrasonographic examination in sheep veterinary practice. Small Ruminant Research, 152: 166-173. http://dx.doi.org/doi:10.1016/j.smallrumres.2016.12 .021

Gonzalez F, Sulon J, Garbayo JM, Batista M, Cabrera F, Calero P, Gracia A, Beckers JF 1999. Early pregnancy diagnosis in goats by determination of pregnancy-associated glycoprotein concentrations in plasma samples. Theriogenology, 52(4): 717-725. https://doi.org/10.1016/S0093-691X(99)00165-X

Green JA, Xie S, Quan X, Bao B, Gan X, Mathialagan N, Beckers JF, Roberts RM 2000. Pregnancyassociated bovine and ovine glycoproteins exhibit spatially and temporally distinct expression patterns during pregnancy. Biology of Reproduction, 62(6): 1624-1631. https://doi.org/ 10.1095/biolreprod62.6.1624
Gürler H, Kaymaz M (2011). Akkaraman ırkı koyunlarda transrektal ve transabdominal muayene tekniği kullanılarak embriyonik ve fötal yaşın belirlenmesi. Ankara Üniversitesi Veteriner Fakültesi Dergisi, 58:99 - 104. https://doi.org/ 10.1501/Vetfak_0000002457

Hussein MS, Wael EB, Deghedy A, El-Desouky AM, Ramoun AA 2017. Serum concentration of pregnancy-associated glycoproteins (PAGs) as a predictor for embryonic/fetal losses and fetal numbers in cross-bred ewes. Life Science Journal, 14(5):106-111. https://doi.org/10.7537/marslsj 140517.15

Jones AK, Gately RE, McFadden KK, Zinn SA, Govoni KE, Reed SA 2016. Transabdominal ultrasound for detection of pregnancy, fetal and placental landmarks, and fetal age before day 45 of gestation in the sheep. Theriogenology, 85(5): 939-945. 10.1016/j.theriogenology.2015.11.002

Kandemir Ç, Adanacıoğlu H, Taşkın T, Koşum N 2019. Türkiye'de koyun ve koyun eti fiyatlarının bölgelere göre çok boyutlu ölçekleme analizi ile karşılaştırılması. Journal of Tekirdag Agricultural Faculty, 16(2): 315-327. https://doi.org/10.33462/ jotaf.529109

Kaplan Y, Özyurtlu N, Köse M, Atlı MO, Küçükaslan I, Kırbaş M 2019. Gebe Konya Merinosu koyunlarında erken gebelikte gebelik ilişkili glikoproteinlerin plazma profilinin belirlenmesi. Atatürk Üniversitesi Veteriner Bilimleri Dergisi, 14(3):307-314. . https://doi.org/10.17094/ ataunivbd. 588666

Karen A, Kovács P, Beckers JF, Szenci O 2001. Pregnancy diagnosis in sheep: Review of the most practical methods. Acta Veterinaria. Brno, 70(2): 115-126. https://doi.org/10.2754/avb200170020115

$\mathrm{Kul} \mathrm{S}$, Akcan A 2002. İvesi ve Ost-Friz x İvesi Melez (F1) kuzularda besi performansı, kesim ve karkas özellikleri. Journal of Research in Veterinary Medicine, 21(1): 1-7.

Küplülü Ş, Çetin Y, Macun HC, Taşdemir U 2002. Akkaraman irkı koyunlarda transrektal ve transabdominal ultrasonografi yöntemi ile erken gebelik tanı sinırlarının belirlenmesi. Lalahan Hayvancılık Araştırma Enstitüsü Dergisi, 42:25-33.

Lobago F, Bekana M, Gustafsson H, Beckers JF, Yohannes G, Aster Y, Kindahl H 2009. Serum profiles of pregnancy-associated glycoprotein, oestrone sulphate and progesterone during gestation and some factors influencing the profiles in Ethiopian Borana and crossbred cattle. Reproduction in Domestic Animals, 44(4): 685-692. 10.1111/j.1439-0531.2007.01049

Mercadante PM, Waters KM, Mercadante VR, Lamb GC, Elzo MA, Johnson SE, Rae DO, Yelich JV, Ealy AD 2013. Subspecies differences in early fetal development and plasma pregnancy-associated glycoprotein concentrations in cattle. Journal of 
Animal Science, 91(8):3693-3701. 10.2527/jas.20126130

Pohler KG, Pereira MH, Lopes FR, Lawrence JC, Keisler DH, Smith MF, Vasconcelos JL, Green JA 2016. Circulating concentrations of bovine pregnancy-associated glycoproteins and late embryonic mortality in lactating dairy herds. Journal of Dairy Science, 99(2):1584-1594. http://dx.doi.org/10.3168/jds.2015-10192

Roberts J, May K, Ajani O, Kaneene J 2019. A comparison of pregnancy diagnosis methods in commercial sheep using lambing as a gold standard. Clinical Theriogenology. 11(2): 107-113.

Rovani MT, Cezar AS, Rigo ML, Gasperin BZ, Nobrega Júnior JE, Torres FD, Gonçalves, PBD, Ferreira R 2016. Evaluation of a bovine pregnancy-associated glycoprotein enzyme-linked immunosorbent assay kit for serological diagnosis of pregnancy in sheep. Ciencia Rural. 46(2): 362-367. http://dx.doi.org/ 10.1590/0103-8478cr20150270

Sousa NM, Ayad A, Beckers JF, Gajewski Z 2006. Pregnancy-associated glycoproteins (PAG) as pregnancy markers in the ruminants. Journal of Physiology and Pharmacology, 57(Supp 8):153-171.

SPSS 2016. IBM SPSS Statistics 24.0 for Windows. Armonk, NY.

Steckeler P, Weber F, Zerbe H, Rieger A, Voigt K 2018. Evaluation of a bovine visual pregnancy test for the detection of pregnancy-associated glycoproteins in sheep. Reproduction in Domestic Animals, 54(2): 280-288. https://doi.org/10.1111/rda.13356

Şireli HD, Tekel N 2013. İvesi erkek kuzularının besi performansı ve karkas özelliklerine süt emme döneminde farklı büyütme sistemlerinin etkisi. Journal of Agricultural Sciences, 19(1): 63-70. https://doi.org/10.1501/Tarimbil_0000001228
Tandiya U, Nagar V, Yadav VP, Ali I, Gupta M, Dangi SS, Hyder I, Yadav B, Bhakat M, Chouhan VS, Khan FA, Maurya VP, Sarkar M 2013. Temporal changes in pregnancy-associated glycoproteins across different stages of gestation in the Barbari goat. Animal Reproduction Science, 142:141-148. https://doi.org/10.1016/j.anireprosci.2013.09.016

Taşan A 2016. Halk Elinde Yetiştirilen İvesi Koyunlarında Laktasyon Süt Verim Özelliklerinin Belirlenmesi ve Genetik Parametrelerin Tahmini. Harran Üniversitesi Fen Bilimleri Enstitüsü Zootekni Anabilim Dalı, Yüksek Lisans Tezi, 46 sy.

Tekel N, Şireli HD, Vural ME 2007. Besi süresinin ivesi erkek kuzuların besi performansı ve karkas özelliklerine etkisi. Journal of Agricultural Sciences, 13(4): 372-378. https://doi.org/10.1501/ Tarimbil_0000000389

Uçar U, Köse M, Atlı MO 2018. Konya Merinosu koyunlarda gebelik ilişkili glikoproteinlerin gebelikteki plazma profili ve erken gebelik tanısında kullanılabilirliği. Dicle Üniversitesi Veteriner Fakültesi Dergisi, 11(2): 77-82.

Ulusoy H, Kaymaz M 2009. Koyunlarda gebelik tanısı. Veteriner Hekimleri Derneği Dergisi, 80(1):31-36.

Xie S, Low RC, Nagel RJ, Kramer KK, Anthony RV, Zoli AP, Beckers JF, Roberts RM 1991. Identification of the major pregnancy-specific antigens of cattle and sheep as inactive members of the aspartic proteinase family. Proceedings of the National Academy of Sciences of the United States of America, 88(22):10247-10251. https://doi.org/ $10.1073 /$ pnas.88.22.10247

Yağanoğlu AM, Topal M 2018. Morkaraman-İvesi ve Tuj ırkı koyunlarda gebelik testlerinin Roc analizi ile karşılaştırılması. Alınteri Journal of Agriculture Sciences, 33(1):29-36. https://doi.org/10.28955/ alinterizbd.347633 